\title{
(- OPEN ACCESS \\ Imatinib dramatically alleviates pulmonary tumour thrombotic microangiopathy induced by gastric cancer
}

\author{
Kana Kubota, ${ }^{1}$ Taro Shinozaki, ${ }^{2}$ Yasushi Imai, ${ }^{1,3}$ Kazuomi Kario $^{1}$
}

Division of Cardiovascular Medicine, Department of Internal Medicine, Jichi Medical University, Shimotsuke, Tochigi, Japan

2Division of Cardiovascular Medicine, Sano-kosei General Hospital, Sano, Tochigi, Japan ${ }^{3}$ Division of Clinical Pharmacology, Department of Pharmacology, Jichi Medical University, Shimotsuke, Tochigi, Japan

\section{Correspondence to}

Dr Kana Kubota,

r0911kk@jichi.ac.jp

Accepted 5 August 2017

CrossMark

\section{To cite: Kubota $\mathrm{K}$}

Shinozaki T, Imai Y, et al. BM Case Rep Published Online First: [please include Day Month Year]. doi:10.1136/ bcr-2017-221032

\section{SUMMARY}

Pulmonary tumour thrombotic microangiopathy (PTTM) is a rare complication of cancer, which can be lethal due to progressive pulmonary hypertension (PH). Several case reports have demonstrated that imatinib, a plateletderived growth factor receptor-tyrosine kinase inhibitor, can improve severe $\mathrm{PH}$ in patients with PTTM.

We describe the case of a 56-year-old woman. Her mean pulmonary arterial pressure (mPAP) was $47 \mathrm{~mm}$ $\mathrm{Hg}$, and her dyspnoea worsened rapidly over several days. Although pulmonary embolism was not observed on $\mathrm{CT}$, enlargement of the para-aortic lymph nodes was detected. Gastro-oesophageal endoscopy revealed signet-ring cell carcinoma. We diagnosed her as having PTTM based on her clinical course, and started treatment with imatinib. Five days after its administration, her mPAP decreased dramatically. She was discharged and lived without symptoms of PH until her death due to systemic metastasis of carcinoma. In some cases of PTTM, imatinib may be an effective therapeutic option for $\mathrm{PH}$.

\section{BACKGROUND}

Pulmonary tumour thrombotic microangiopathy (PTTM) is a rare but fatal pulmonary complication of cancer, which was first described by von Herbay et al. The clinical presentation typically is acute dyspnoea, followed by a very rapid clinical course, progressing to death in a matter of hours to days. ${ }^{1}$ In fact, it has been reported that only 7 of 103 patients were pathologically diagnosed with PTTM while still alive. ${ }^{2}$

Platelet-derived growth factor (PDGF) stimulation has been reported to be involved in the proliferation and anti-apoptosis of pulmonary artery endothelial cells and smooth muscle cells in patients with pulmonary hypertension $(\mathrm{PH}) .^{3-5}$ PDGF is also involved in the progression of PTTM. ${ }^{6}$ Several case reports from Japan have demonstrated that imatinib, a PDGF receptortyrosine kinase inhibitor, can improve severe $\mathrm{PH}$ in patients with PTTM. Here, we report a case of PTTM that was alleviated dramatically with imatinib therapy.

\section{CASE PRESENTATION}

A 56-year-old woman had a 2-month history of oedema and exertional dyspnoea (WHO functional class II). She had no prior diseases or relevant family history. She was admitted to a nearby hospital where she was found to have severe PH. Figure 1 shows CT; it showed no thrombus in the pulmonary artery as well as no parenchymal lesion such as malignant tumour, lymphangitis carcinomatosa or interstitial

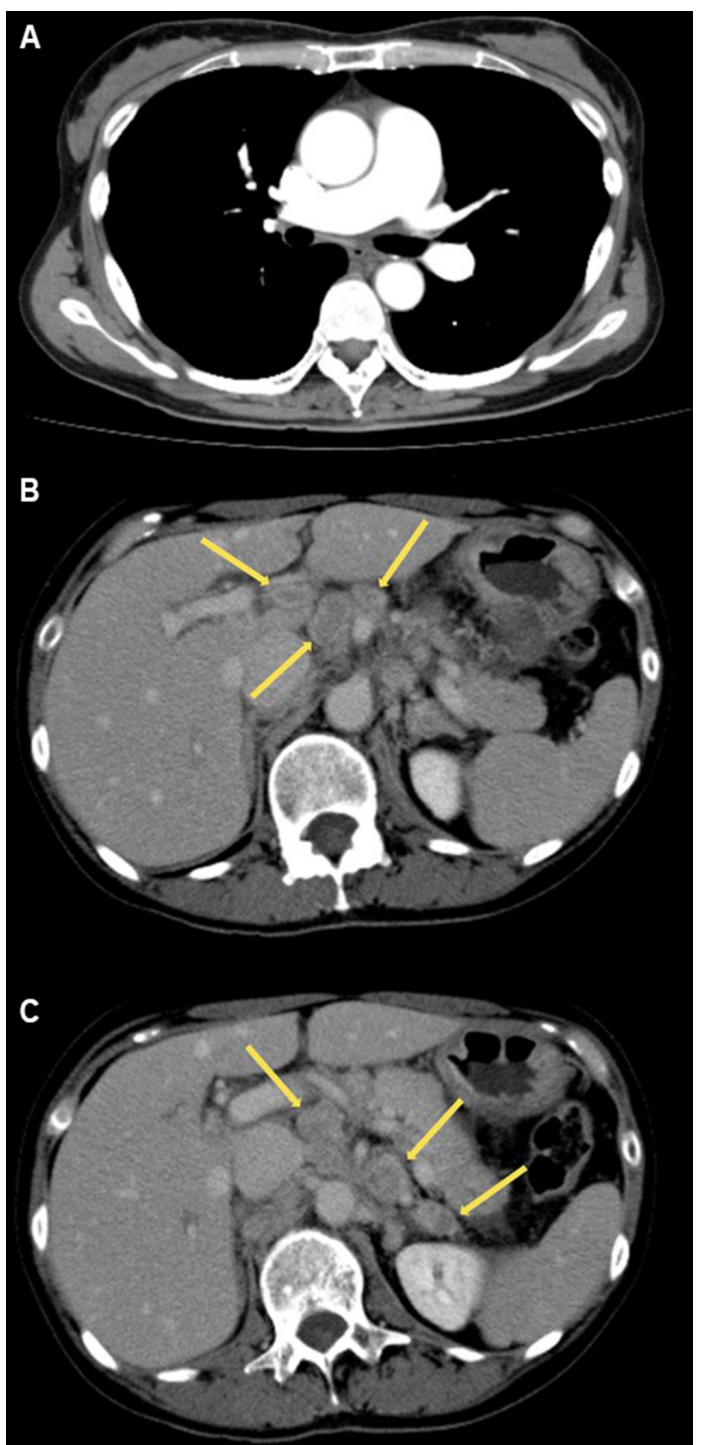

Figure 1 CT on admission. (A) Mediastinal window image of lung field shows no thrombus in the pulmonary artery. (B) Lung window image shows no abnormality in the parenchymal parenchyma. (C,D) Mediastinal window image of abdomen shows enlargements of the paraaortic lymph nodes (yellow arrow). 


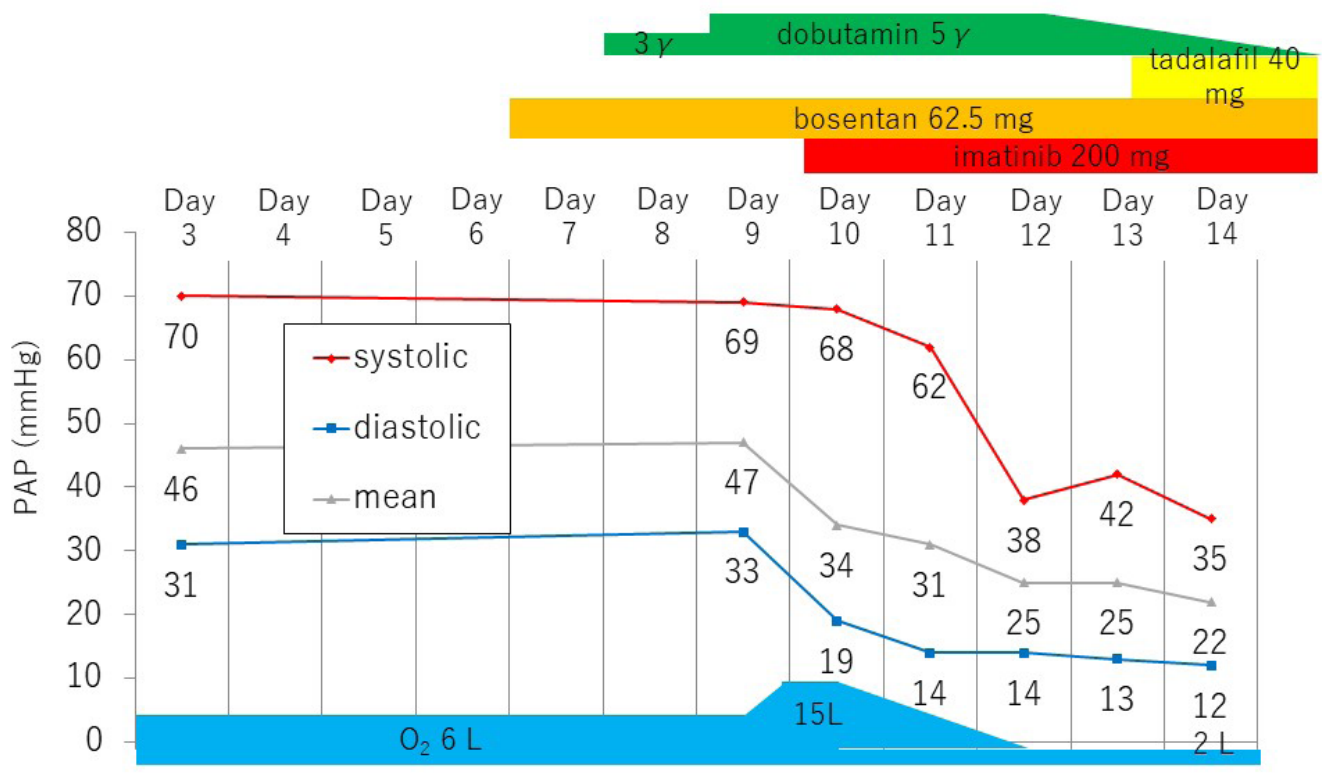

Figure 2 Clinical course. PAP, pulmonary arterial pressure; $\gamma, \mu \mathrm{g} / \mathrm{kg} / \mathrm{min}$.

pneumonia. However, enlargement of the para-aortic lymph nodes was found.

\section{INVESTIGATIONS}

Right heart catheterisation showed significant $\mathrm{PH}$ (mean pulmonary arterial pressure (mPAP), $47 \mathrm{~mm} \mathrm{Hg}$ ). In Japan, the probability of Helicobacter pylori infection is high; it is known that gastric cancer is much more frequent than in Western countries. In this case, enlargement of the para-aortic lymph nodes was recognised, so we performed gastro-oesophageal endoscopy at an early stage. Gastric cancer was detected, pathologically diagnosed as poorly differentiated adenocarcinoma involving the signet-ring cells.

\section{TREATMENT}

Figure 2 shows the clinical course, with PAP measured directly with a Swan-Ganz catheter indwelling from the right internal jugular vein. We started sequential oxygen, dobutamine and bosentan, but
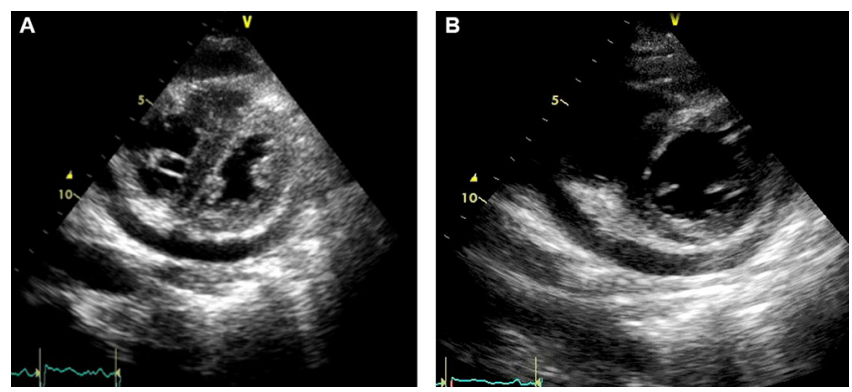

Figure 3 Short axis view echocardiograms. (A) On admission, the right ventricle was remarkably dilated, suggesting severe pulmonary hypertension (PH). (B) Three days after imatinib administration, there was obvious improvement of severe $\mathrm{PH}$. there was no improvement in her haemodynamics. Her respiratory condition deteriorated rapidly, and we diagnosed her as having PTTM based on her clinical course. After consulting Dr Hatano from The University of Tokyo, who reported a similar case of PTTM, we started treatment with imatinib (200 mg once daily) on day 10. Because imatinib therapy was off-label, we obtained urgent approval from the institutional ethics committee and received written informed consent from the patient.

\section{OUTCOME AND FOLLOW-UP}

After administration of $200 \mathrm{mg}$ imatinib, her PAP decreased dramatically. Five days later, her haemodynamics normalised (mPAP, $12 \mathrm{~mm} \mathrm{Hg}$ ) and her dyspnoea disappeared. Figure 3 shows her echocardiograms before and after imatinib administration. Although mild pericardial effusion remained, the prominent right heart dilatation showed obvious improvement.

She was discharged and periodically visited our hospital for chemotherapy including titanium silicate- 1 and oxaliplatin. She did not experience recurrence of $\mathrm{PH}$, and died from systemic metastasis of carcinoma 7 months later.

\section{DISCUSSION}

In our case, imatinib remarkably improved acute right heart failure due to PTTM associated with signet-ring cell carcinoma.

Imatinib is a tyrosine kinase inhibitor approved as an anticancer drug for chronic myelogenous leukaemia, Philadelphia chromosome-positive acute lymphoid leukaemia, KIT antibody-positive gastrointestinal stromal tumour and idiopathic hypereosinophilic syndrome. Imatinib inhibits phosphorylation of the BCR-ABL fusion protein, c-KIT protein and PDGF receptor, subsequently blocking many intracellular downstream signalling pathways. Dasatinib, another tyrosine kinase inhibitor, has recently been drawing attention as a cause of drug-induced pulmonary arterial hypertension $(\mathrm{PAH})$, whereas imatinib has 
Table 1 Summary of cases with PTTM treated with imatinib

\begin{tabular}{|c|c|c|c|c|c|c|}
\hline & Patient 1 & Patient 2 & Patient 3 & Patient 4 & Patient 5 & $\begin{array}{l}\text { Patient } 6 \\
\text { (our case) }\end{array}$ \\
\hline Age at onset, y & 47 & 61 & 64 & 61 & 45 & 56 \\
\hline Sex & $\mathrm{F}$ & $\mathrm{M}$ & $\mathrm{F}$ & $\mathrm{F}$ & $\mathrm{F}$ & $\mathrm{F}$ \\
\hline Author & Ogawa A & Higo $\mathrm{K}$ & Minatsuki S & Fukuda I & Fukuda I & Kubota K \\
\hline Year of report & 2013 & 2014 & 2015 & 2015 & 2016 & 2017 \\
\hline Primary disease & $\begin{array}{l}\text { Gastric adenocarcinoma } \\
\text { (signet-ring cells) }\end{array}$ & Colorectal cancer & $\begin{array}{l}\text { Gastric adenocarcinoma } \\
\text { (signet-ring cells) }\end{array}$ & Breast cancer & Breast cancer & $\begin{array}{l}\text { Gastric adenocarcinoma } \\
\text { (signet-ring cells) }\end{array}$ \\
\hline $\begin{array}{l}\text { Drugs } \\
\text { administered }\end{array}$ & $\begin{array}{l}\text { Imatinib } 100 \mathrm{mg} \text { bosentan } \\
93.75 \mathrm{mg} \text { epoprostenol } 27 \mathrm{ng} / \\
\mathrm{kg} / \mathrm{min}\end{array}$ & $\begin{array}{l}\text { Imatinib } 50 \rightarrow 200 \mathrm{mg} \\
\text { bosentan tadalafil }\end{array}$ & $\begin{array}{l}\text { Imatinib } 200 \mathrm{mg} \\
\text { sildenafil } 60 \mathrm{mg} \\
\text { ambrisentan } 10 \mathrm{mg}\end{array}$ & $\begin{array}{l}\text { Imatinib } 200 \rightarrow 400 \mathrm{mg} \\
\text { tadalafil } 40 \mathrm{mg}\end{array}$ & Imatinib $200 \rightarrow 400 \mathrm{mg}$ & $\begin{array}{l}\text { Imatinib } 200 \mathrm{mg} \\
\text { bosentan } 62.5 \mathrm{mg} \\
\text { tadalafil } 40 \mathrm{mg}\end{array}$ \\
\hline $\begin{array}{l}\text { Mean PAP after } \\
\text { administration of } \\
\text { imatinib }\end{array}$ & $47 \rightarrow 25 \mathrm{~mm} \mathrm{Hg}$ & $48 \rightarrow 35 \mathrm{~mm} \mathrm{Hg}$ & $48 \rightarrow 33 \mathrm{~mm} \mathrm{Hg}$ & $60 \rightarrow 56 \mathrm{~mm} \mathrm{Hg}$ & $27 \rightarrow 30 \mathrm{~mm} \mathrm{Hg}$ & $47 \rightarrow 22 \mathrm{~mm} \mathrm{Hg}$ \\
\hline Chemotherapy & TS-1 $40 \mathrm{mg}$ & $\begin{array}{l}\text { Bevacizumab } 5 \mathrm{mg} / \mathrm{kg} \\
\text { TS-1 } 100 \mathrm{mg}\end{array}$ & TS-1 & Eribulin & Capecitabine & $\begin{array}{l}\text { TS-1 } \\
\text { oxaliplatin }\end{array}$ \\
\hline Surgical therapy & $(-)$ & $(-)$ & Total gastrectomy & $(-)$ & $(-)$ & $(-)$ \\
\hline Survival time & 9 months & 12 months & 12 months & 54 days & 24 days & 7 months \\
\hline Cause of death & Metastasis & Infection & Metastasis & Respiratory failure & Respiratory failure & Metastasis \\
\hline
\end{tabular}

PAP, pulmonary arterial pressure; PTTM, pulmonary tumour thrombotic microangiopathy; TS, titanium silicate.

been reported to be effective in patients with $\mathrm{PAH}$ in a recent randomised study (IMPRES study). However, serious adverse events and study drug discontinuations were common. ${ }^{7}$ PTTM is thought to occur by obstruction of the pulmonary arterioles by microembolisms of tumour cells, thrombus formation induced by activation of thrombogenic cascades on the surface of tumour embolisms and abnormal proliferation of vascular cells caused by growth factors, such as PDGF and vascular endothelial growth factor, which are induced by tumours. ${ }^{689}$ In 2013, Ogawa et al reported the first case of PTTM with severe PH treated successfully with imatinib. ${ }^{6}$ However, few cases of PTTM treated with imatinib have been reported in Japan. We summarise the previous literature and our case in table $1 .^{10-13}$ In this table, in patient 3 , total gastrectomy was performed for mass reduction of the tumour, after which the patient's mPAP decreased from 33 to $13 \mathrm{~mm} \mathrm{Hg}$. We also considered gastrectomy in our case, but the tumour mainly involved the para-aortic lymph nodes rather than the stomach itself. Therefore, we did not perform surgery, and it is noteworthy that her PAP improved promptly after administration of imatinib alone.

Imatinib can be particularly effective in patients with PTTM associated with signet-ring cell carcinoma. Fujishiro et al reported 103 patients with PTTM, among whom the most frequent primary cancer was gastric (58 cases), followed by lung (10 cases), breast ( 7 cases), cancer of unknown primary ( 55 cases), ovarian (5 cases) and bladder (4 cases). ${ }^{2}$ As shown in table 1 , imatinib was effective in three cases of signet-ring cell carcinoma, including our case, but was weaker in cases of colon (patient 2) and breast (patients 4 and 5) cancer. The mechanism is still unclear, but it has been suggested that production of growth factors, including PDGF, might be different depending on the tumour characteristics.

The limitation of this report is that there are few cases of PTTM treated with imatinib, which has not been adopted for $\mathrm{PH}$. This is because PTTM progresses quickly and patients often die before drug administration. Therefore, further accumulation of cases is necessary.

In some cases, imatinib remarkably improves acute right heart failure caused by PTTM. Furthermore, imatinib can be highly effective in cases of PTTM caused by gastric adenocarcinoma, especially signet-ring cell carcinoma. Because patients with PTTM deteriorate rapidly, treatment with imatinib should be considered immediately.

\section{Learning points}

Pulmonary tumour thrombotic microangiopathy (PTTM) is a rare haemodynamic complication of cancer, which can be lethal due to rapid progression of right heart failure caused by pulmonary hypertension.

- In some cases, imatinib remarkably improves acute right heart failure caused by PTTM.

- Because patients with PTTM deteriorate rapidly, treatment with imatinib should be considered immediately.

Contributors KK and TS were physicians in charge and wrote the manuscript. YI gave precise advice on medical treatment and refined the manuscript. KK supervised the aforementioned staffs and had responsibility for this case report.

\section{Competing interests None declared.}

Patient consent Detail has been removed from this case description/these case descriptions to ensure anonymity. The editors and reviewers have seen the detailed information available and are satisfied that the information backs up the case the authors are making.

Ethics approval Because imatinib therapy was off-label, we obtained urgent approval from the institutional ethics committee and received written informed consent from the patient for therapy itself as well as publication. The consent form written in Japanese is attached as PDF files.

Provenance and peer review Not commissioned; externally peer reviewed.

Open Access This is an Open Access article distributed in accordance with the Creative Commons Attribution Non Commercial (CC BY-NC 4.0) license, which permits others to distribute, remix, adapt, build upon this work non-commercially, and license their derivative works on different terms, provided the original work is properly cited and the use is non-commercial. See: http://creativecommons.org/ licenses/by-nc/4.0/

(C) BMJ Publishing Group Ltd (unless otherwise stated in the text of the article) 2017. All rights reserved. No commercial use is permitted unless otherwise expressly granted.

\section{REFERENCES}

1 von Herbay A, Illes A, Waldherr R, et al. Pulmonary tumor thrombotic microangiopathy with pulmonary hypertension. Cancer 1990;66:587-92. 
2 Fujishiro T, Shuto K, Shiratori T, et al. A case report of pulmonary tumor thrombotic microangiopathy (PTTM) caused by esophageal squamous cell carcinoma. Esophagus 2013;10:247-51.

3 Ogawa A, Nakamura K, Matsubara H, et al. Prednisolone inhibits proliferation of cultured pulmonary artery smooth muscle cells of patients with idiopathic pulmonary arterial hypertension. Circulation 2005;112:1806-12.

4 Fujio H, Nakamura K, Matsubara H, et al. Carvedilol inhibits proliferation of cultured pulmonary artery smooth muscle cells of patients with idiopathic pulmonary arterial hypertension. J Cardiovasc Pharmacol 2006;47:250-5.

5 Ikeda T, Nakamura K, Akagi S, et al. Inhibitory effects of simvastatin on plateletderived growth factor signaling in pulmonary artery smooth muscle cells from patients with idiopathic pulmonary arterial hypertension. J Cardiovasc Pharmacol 2010;55:39-48.

6 Ogawa A, Yamadori I, Matsubara 0, et al. Pulmonary tumor thrombotic microangiopathy with circulatory failure treated with imatinib. Intern Med 2013;52:1927-30

7 Hoeper MM, Barst RJ, Bourge RC, et al. Imatinib mesylate as add-on therapy for pulmonary arterial hypertension: results of the randomized IMPRES study. Circulation 2013;127:1128-38.
8 Kim R, Emi M, Arihiro K, et al. Chemosensitization by STI571 targeting the plateletderived growth factor/platelet-derived growth factor receptor-signaling pathway in the tumor progression and angiogenesis of gastric carcinoma. Cancer 2005:103:1800-9.

9 Yokomine $\mathrm{T}$, Hirakawa $\mathrm{H}$, Ozawa $\mathrm{E}$, et al. Pulmonary thrombotic microangiopathy caused by gastric carcinoma. J Clin Pathol 2010;63:367-9.

10 Minatsuki S, Miura I, Yao A, et al. Platelet-derived growth factor receptor-tyrosine kinase inhibitor, imatinib, is effective for treating pulmonary hypertension induced by pulmonary tumor thrombotic microangiopathy. Int Heart $J$ 2015;56:245-8.

11 Higo K, Kubota K, Takeda A, et al. Successful antemortem diagnosis and treatment of pulmonary tumor thrombotic microangiopathy. Intern Med 2014:53:2595-9.

12 Fukada I, Araki K, Minatsuki S, et al. Imatinib alleviated pulmonary hypertension caused by pulmonary tumor thrombotic microangiopathy in a patient with metastatic breast cancer. Clin Breast Cancer 2015;15:e167-e170.

13 Fukada I, Araki K, Kobayashi K, et al. Imatinib could be a new strategy for pulmonary hypertension caused by pulmonary tumor thrombotic microangiopathy in metastatic breast cancer. Springerplus 2016;5:1582.

Copyright 2017 BMJ Publishing Group. All rights reserved. For permission to reuse any of this content visit http://group.bmj.com/group/rights-licensing/permissions.

BMJ Case Report Fellows may re-use this article for personal use and teaching without any further permission

Become a Fellow of BMJ Case Reports today and you can:

- Submit as many cases as you like

- Enjoy fast sympathetic peer review and rapid publication of accepted articles

- Access all the published articles

- Re-use any of the published material for personal use and teaching without further permission

For information on Institutional Fellowships contact consortiasales@bmjgroup.com

Visit casereports.bmj.com for more articles like this and to become a Fellow 